\title{
Systematically Distorted Communication: An Impediment to Social and Political Change
}

\author{
Alan G. Gross \\ Department of Communication Studies \\ 238 Ford Hall \\ University of Minnesota-Twin Cities \\ Minneapolis, MN 55455 \\ agross@umn.edu
}

\begin{abstract}
After reconstructing the theory of systematically distorted communication from Habermas's corpus, I refine and elaborate it by means of a focused, structured comparison among three of its instances. Next, I explore its critique, the first step toward emancipation for its victims. I show that critique is possible within the confines of Habermas's theory by recourse to a minimalist concept of rationality and a version of the truth that, while it transcends consensus, avoids the unwelcome metaphysical baggage of truth with a capital $\mathrm{T}$. For critique to be complete, it must be supplemented by the full range of rhetorical proofs, a range consonant with the constraints and affordances of informal logic. But there are limits to the power of critique thus enhanced: while the demystification of systematically distorted communication can reveal the institutional arrangements that generate it, only social and political action can alter these arrangements.
\end{abstract}

Résumé:

Keywords: communicative action, discourse, drug promotion, emancipation, Freud, Habermas, Nazi language, rhetoric, sexist language, systematically distorted communication.

\section{Introduction}

The pervasive employment of Nazi language in the Europe of World War II, the routine use of sexist language in the West, the (C) Alan G. Gross. Informal Logic, Vol. 30, No. 4 (2010), pp. 335360 . 
biased prescription practices of American physicians influenced by drug company promotions - these varied phenomena are all examples of communication in which at least one party is self-deceived, a phenomenon Habermas calls systematically distorted communication. It is a phenomenon he virtually ignores in the later stages of his career, a marginalization that may be the reason that scholars have generally neglected its detailed explication. This double neglect is unfortunate. Communicative action, a theoretical concept at the center of Habermas's later work, must remain inoperative so long as systematically distorted communication is in place. Consequently, systematically distorted communication constitutes an impediment to communication free from the distortion of power differentials and, as a result, to social and political change. It is an impediment all the more formidable because it is by definition invisible to its victims.

From an examination of Habermas's entire corpus, I reconstruct the definition of systematically distorted communication; then, I examine those cases just mentioned-Nazi language, sexist language, unacknowledged prescribing bias - with the aim of refining that definition. My method is borrowed from comparative political scientist, Alexander George. According to George, case analysis differs from more rigorous designs. Experimental and quasi-experimental designs are characterized by controls; statistical designs are characterized by their mathematical equivalent. The comparison of cases provides no such constraints. In the words of George, "the comparative analyst [of cases] can manipulate conditions neither situationally, as is done with the experimental method, nor mathematically, as with the statistical method. Instead, ... controlled comparison must rely on cruder methods" (George 1982, 39). As a consequence of this limitation, comparative case analyses can say nothing about frequency distributions, nor can it permit inferences from "the few cases studied to the total universe or class of events of which these cases are instances" (ibid., 23). As George makes clear, "this research strategy is more likely to be helpful in building, refining, and elaborating theory than subjecting it to decisive tests" (ibid., 33). To say that these tests are not decisive, however, is not to say that theory cannot be refined and corrected "in the light of stubborn empirical findings" (Blumer 1980, 150). That I cannot say something definitive by using this method does not mean that I cannot thereby advance our understanding of systematically distorted communication.

George recommends the focused, structured comparison of cases. As a first step, he suggests that the cases selected "differ from one another on some dimensions judged significant by the researcher" (George \& McKeown 1985, 25). These are the research's focus. At this point, the researcher formulates "theoretically relevant questions to guide the examination of each case" 
(ibid., 41). These constitute the structure of the study. In what follows, I have tried to follow George's advice; I have selected three cases, each of which I regard as an instance of systematically distorted communication. The cases contrast in that Nazi language pervades the whole of society; sexist language pervades one aspect of whole societies; biased prescription practices pervade one segment of society.

Focused, structured comparison is not entirely foreign to Habermas scholarship. In a collection edited by Craig Calhoun (1992), Habermas and the Public Sphere, the contributors redefine that sphere by confronting Habermas's definition in his Structural Transformation of the Public Sphere (1996) with instances that force its elaboration and refinement. They point out, for example, that Habermas virtually ignores the exclusion of women from the $19^{\text {th }}$ century public sphere, and unreasonably excludes the working class from its definition. Although in effect, the collection makes use of George's method, in fact, individual scholars analyze individual cases in standard fashion, one case per scholar. In contrast to those contributing to Habermas and the Public Sphere, I have used focused, structured comparison explicitly. In so doing, I am taking advantage of Habermas's great strength as a thinker: from his scrutiny of the tangle of communicative events, he sees emerge concepts of considerable theoretical significance for political philosophy, political science, sociology and argument theory. Once discovered, such concepts serve purposes that are, equally, heuristic and explanatory: they permit us to search out and explore their possible historical and contemporary instances. It is at this point that George's method can usefully intervene. Employing it, we can refine and modify the theory and, as a consequence, redefine its scope. In the particular case of systematically distorted communication, such scrutiny leads to a re-analysis of emancipation, a theme that appears first in Habermas's early Knowledge and Human Interests (1971), but persists throughout his career.

\section{Defining systematically distorted communication}

According to Habermas's theory, communication can derail in two ways: manipulation and systematically distorted communication. In manipulation, "at least one of the participants is deceiving the other(s) regarding the non-fulfillment of the conditions of communicative action which he or she apparently accepted" Habermas 1982, 264). In contrast, in systematically distorted communication "at least one of the participants is deceiving himself or herself regarding the fact that he or she is actually behaving strategically while he or she has only apparently adopted an attitude oriented to reaching understanding" (ibid., 264; his emphasis). Manipulation is 
about deception; systematically distorted communication, about self-deception. In manipulation, a border is crossed. Communicative becomes strategic action: its goal is no longer mutual understanding, but an end deliberately hidden from one of interlocutors. In systematically distorted communication, a border has also been crossed. Interlocutors deceive themselves; they think they are in control of exchanges whose purpose is mutual understanding; in fact, they have ceded control. In the cases of self and family, they have ceded control to other family members or internalized others; in the case of society and of the political order, to governments or special interests.

It is in Knowledge and Human Interests that Habermas applies systematically distorted communication to the self; it is in this work that he assesses the impact of maladaptive defense mechanisms on language use. He finds that, while the public language of neurotics remains apparently unaffected, this specious normality hides from others and from themselves the true meaning of their utterances, their status as symptoms stemming from childhood trauma:

The original defensive process takes place in a childhood conflict situation as flight from a superior partner. It removes from public communication the linguistic interpretation of the motive of action that is being defended against. In this way the grammatical structure of public language remains intact, but portions of its semantic content are privatized. Symptom formation is a substitute for a symbol whose function has been altered. The split-off symbol has not simply lost all connection with public language; rather, this grammatical connection has as it were gone underground. It derives its force from confusing the logic of the public usage of language by means of semantically false identifications. At the level of the public text, the suppressed symbol is objectively understandable through rules resulting from contingent circumstances of the individual's life history, but not connected with it according to intersubjectively recognized rules. That is why the symptomatic concealment of meaning and corresponding disturbance of interaction cannot be understood either by others or by the subject himself. (Habermas 1971, 257; his emphasis; translation corrected).

In "Reflections on Communicative Pathology," a chapter in On the Pragmatics of Social Interaction (2001a), Habermas extends systematically distorted communication from self to family. In making this extension, he recognizes that the self the growing child becomes is the creation of interaction with significant others, 
an insight borrowed from the American philosopher, George Herbert Mead. In a famous passage, Mead (1964) compares forming of the self with learning to play baseball. He makes the point that, in baseball as in life, to play any position, is, simultaneously, to learn how all positions are played:

The play antedates the game. For in a game there is a regular procedure, and rules. The child must not only take the role of the other, as he does in the play, but he must assume the various roles of all the participants in the game, and govern his action accordingly. If he plays first base, it is as the one to whom the ball will be thrown from the field or from the catcher. Their organized reactions to him he has embedded in his own playing of the different positions, and this organized reaction becomes what I have called the "generalized other" that accompanies and controls his conduct. And it is this generalized other in his experience which provides him with a self. (Mead 1964, 285)

Habermas draws on R.D. Laing to extend this insight to systematically distorted communication. A neurotic generalized other, formed in the family, vigorously defends itself: "I have the impression," Laing says, "that most people come to feel that they are the same continuous being from womb to tomb. And that this 'identity,' the more it is phantasy, is the more intensely defended" (quoted in Habermas 2001a, 156). Within the family, neurotic fantasies can proliferate in networks of distorted communication. Upset, a family member, interprets another's calm reception of his emotional turmoil, not as concern, but as indifference. As a consequence, upset turns to anger, anger then met by reciprocating anger (ibid., 157-58). Another result of miscommunication is possible, equally pathological. As a consequence of the mutual adjustments of systematically distorted communication, a pseudo-consensus can form beneath whose apparently calm surface hostility festers (ibid., 165). In either case, power ceded to a neurotic inner dynamic has extended its scope; it has entered into the process by which society produces selves.

Habermas's focus on the family allows him to leap from self to society: "The same configurations that drive the individual to neurosis," he says, "move society to establish institutions" $(1971,276)$. In this passage, Habermas seems to be saying that society's institutions are precisely analogous to neuroses. Interpreted according his later work (1987b, 153-97), his theory of system and life-world, this claim must be revised; social and political institutions are pathological only to the extent that they represent rigid responses analogous to the neurotic's; just as some neurotics have a compul- 
sion to repeat their actions incessantly, regardless of reality, so some economies turn out goods for sale regardless of whether consumers want or can afford these goods. The networks of belief that such maladaptive institutions embody and enact are analogous to the disturbances in the psyche that are at the root of systematically distorted communication; they differ in that the systematically distorted communication they generate is shared by significant social groups and even by whole societies. At the level of politics and social practice, Nazi language, sexist language, biased prescription practices are analogous to neuroses.

Habermas's early misstep in analogizing psychoanalytic theory ought not to bring into question the legitimacy of employing the essentials of this theory analogously in social and political contexts. It is Habermas's friend, collaborator and translator, Thomas McCarthy, who makes the strongest case possible for the disanalogy between therapeutic and social and political contexts. In therapeutic contexts, he asserts, patients are by definition suffering, a suffering that must be maintained if treatment is to be successful. Moreover, patients resist the knowledge that will lead to their cure, a resistance that must be "worked through" over years of treatment under conditions of transference, the projection of childhood fears and desires onto the analyst (McCarthy 1982, 211-13). There is, McCarthy points out, no precise equivalent at the social and political level to the maintenance of suffering, to resistance, to working through, or to transference.

Although clearly aware of these arguments, Habermas has not in any way attenuated his commitment to the analogy between psychoanalytic and social and political emancipation, the goals, respectively, of personal and social and political change. In an interview conducted in 1986, he says of the emancipatory interest that it "is not just a contingent value-postulate: that people want to get rid of certain sufferings. No, it is something so profoundly in the structure of human societies - the calling into question, and deep-seated wish to throw off, relations which repress you without necessity" (Dews 1986, 198; see also Habermas 2003, 180-81). To be emancipated from Nazi language, sexist language, and biased prescription practices, to overcome the deleterious effects to which these practices lead, we must undergo a process roughly analogous to working through, a process that cannot be successful without the transference of hopes and fears to designated leaders who, like the analyst, are in authority, but are in no sense authoritarian (see White 1988, 88-89 and Warren 1995, 192).

At political and societal levels, we call the shared networks of belief that ground self-deception and impede ameliorative change ideologies. (Habermas 1971, 274-84). The self-deception such ideologies embody has as its purpose the justification of inequities in power in economic, social, or political life. Those who benefit from 
such inequities, acting to preserve their gains, intervene through the power of the state to substitute for the legitimacy that can be procured only from critical debate in the public sphere, ideology, its ersatz counterpart. In "Hannah Arendt: On the Concept of Power," Habermas explicitly sketches a genealogy in which such power manifests itself not as an imposition of force, but as a barrier to the exploration and exposure of ideological justification in the public sphere:

Structural violence is not manifest as violence; instead it blocks in an unnoticed fashion those communications in which are shaped and propagated the convictions effective for legitimation. Such a hypothesis about unnoticed yet effective barriers to communication can explain the formation of ideologies; they can make plausible how convictions are formed by which the subjects deceive themselves about themselves and their situation. Illusions that are afforded the power of common convictions are what we name ideologies. (Habermas 1983, 184; his emphasis)

Structural violence creates ideologies; in turn, ideologies create systematically distorted communication. To Habermas, for example, the Third Reich differs from such democratic regimes as the United States in that the former is a "political order that isolates its citizens from one another through mistrust and suppresses the public exchange of their opinions." The Third Reich is a regime dominated by an ideology, a regime that dominates through real and structural violence and through its linguistic manifestation, systematically distorted communication (Habermas 1983, 176).

Before proceeding further, I would like to make a conceptual distinction that Habermas does not make, one between ideology-a network of taken-for-granted convictions - and hegemony, a network that consists of "the whole body of practices and expectations, over the whole of living; our senses and assignments of energy, or shaping perceptions of ourselves and our world" (Williams 1977, 110; see also Eley 1992). On this reading, ideologies expressed in the form of systematically distorted communication are the visible manifestations of hegemonic regimes.

It is the pervasiveness of hegemonic regimes, so deeply embedded and variously expressed in social, political, economic, and cultural institutions, that makes institutional change so difficult, even in Western liberal democracies in which active public spheres remain a permanent possibility. Hegemonies are not in themselves coercive; only in totalitarianism are hegemonic regimes fully identified with the coercive state. Thus we must distinguish among the three examples of systematically distorted communication that fol- 
low, between the Nazi case, the totalitarian state in which domination by coercion is abetted by persuasion, and the cases of sexist language and drug promotion, instances in the liberal democracies of the West in which persuasion combines with a variety of institutional structures to abet domination. These distinctions are vital if we are effectively to differentiate among the forms of emancipation potentially available to societies at large: while the Nazis must be overthrown, to eliminate sexism and biased prescription practices, institutions and the general public must be induced to change their practices.

\section{Systematically distorted communication: Nazi language}

We can perceive how deeply pervasive Nazi language was, how thoroughly implanted in minds of its intended recipients, by examining an anecdote from Victor Klemperer's The Language of the Third Reich (2002). Born the son of a rabbi, Klemperer had converted to Lutheranism with his father's blessing. But his new religion did not protect him from the Nazi gas chambers; only his marriage to an "Aryan" did. But even this protection was of no use toward the end of the war. About to be shipped to a death-camp, this inhabitant of Dresden was saved by the Allied fire-bombing of that city, and the chaos that ensued, a chaos that permitted him to discard his yellow Star of David and travel without papers. During this journey, he met a Lithuanian pharmacist with whom he struck up a friendship. She was a passionate opponent of the war and no friend of the Nazis. "I never liked [Hitler's] arrogant attitude toward other nations," she says; "my grandmother is Lithuanianwhy should she, why should I be any less worth than some of pure German blood?"

Klemperer suggests that this argument might apply equally to Jews. But the pharmacist demurs: "In the case of the Jews he may well be right, that's a somewhat different case." Klemperer asks if she knows any Jews. "No," she says, "I've always avoided them, they give me the creeps. You hear and read such a lot about them." Their conversation is interrupted by an air-raid, a moment of terror, until

finally, [the Allied planes] were gone, and we could straighten up and return from the dark and cold stairs into the light and warmth of the pharmacy, like coming back to life. "Let's go to bed now," I said, "experience has shown that there won't be another alert before tomorrow morning." Suddenly, and with a burst of energy as if she were ending a lengthy dispute, the otherwise gentle little woman replied, "And it is a Jewish war after all [Und es is 
doch der jüdische Krieg]" (Klemperer 2002, 180-81;

Klemperer 1975, 232)

Nazi language, of which her last response is an example, is systematically distorted communication, the symbolic expression of the Nazi hegemonic regime; it meets Habermas's criterion in that at least one of the interlocutors is self-deceived. More commonly in the Third Reich, both were self-deceived: "Nazism," Klemperer avers, "permeated the flesh and blood of the people through single words, idioms and sentence structures which were imposed upon them and taken on board mechanically and unconsciously." In such situations, "clichés do indeed soon take hold of us. 'Language which writes and thinks for you"' $(2002,15 ; 27)$. Klemperer means this definition literally: "If someone replaces the words 'heroic' and 'virtuous' with 'fanatical' for long enough, he will come to believe that a fanatic really is a virtuous hero, and that no one can be a hero without fanaticism" (ibid., 16). So pervasive is Nazi language in space that everywhere Klemperer wanders in his post-Dresden pilgrimage, he hears its idioms, its turns of phrase; so enduring is it in time, that he hears these regularly even in the post-war period (ibid., 14, 259, 281). So sweeping is the force of Nazi language that, during the Third Reich, it is routinely used even by the Jews, its intended victims (ibid., 101-102, 190200).

Nazi language has the inner coherence that stems from the fact that it is only the linguistic manifestation of an ideology, a world view. To Klemperer, Nazism is Romanticism shorn of its humanitarian ideal, expressed in a language from which words characteristic of the Enlightenment, words like "intelligence" and "humanitarianism," have been expunged (ibid., 161). Indeed, because words such as humanitarianism [Humanität] are "tainted by the stench of Jewish liberalism," another German term is routinely substituted: Menschlichkeit (ibid., 252).

It is in the fires of nationalism and chauvinism that this perverse Romanticism is transformed into Nazi ideology:

It has been said that it was the humanitarian ideal which saved the Romantics (or, according to the Nazis, prevented them) from drawing the obvious conclusions from their sense of being the Chosen Teutonic People. But inflamed into nationalism and chauvinism, the awareness of national identity burns through this protective shield. The sense of a common bond linking humanity is entirely lost; anything of real human value is to be found in one's own people. (ibid., 139) 
The Nazi world view is realized in the Nazi state, a totalitarian regime in which citizenship is not a matter of conviction but of faith, a fantasy of eternal certitudes. Raised to religious status, Nazism "was accepted by millions as gospel because it appropriated the language of the gospel" (ibid., 211-18). The Third Reich is eternal; Hitler is the agent of Providence. He is the secular equivalent of Christ; his followers are his apostles; those who died founding Nazism are its martyrs. A soldier who falls in battle dies "believing in his Führer to the last. The complete subordination of individuals to an Idea is central: "one of their banners contends that 'You are nothing, your people is everything"" [Du bist nichts, dein Volk ist alles] (ibid., 23). ${ }^{1}$ Just as Christians are given saint's names, so true Germans are given names that signal their Teutonic origin: Dieter, Detlev, Uwe, Margit, Ingrid, Uta (ibid., 75). Words sacred to Nazism-folk, blood, soil, system, movement, storm (ibid., 30, 67-68, 98, 121, 199, 226, 229)—cannot be repeated too often.

In addition to being Romantic in origin and theological in temper, Nazi ideology is Manichean, a characteristic realized lexically in networks of superlatives and pejoratives. Germany has the best soldiers supplied with the best weapons; its battles are the greatest in world history; its enemies are incapable of real resistance. Of the D-Day invasion, for example, Goebbels says: "If the enemy really has the intention of starting an operation on which everything depends with something as ludicrous as this, then good night!" (ibid., 222). Given the routine superlatives by which the Third Reich is represented, it is hardly surprising that, in the face of defeat, a corresponding network of euphemisms develops and grows. The German army is never defeated; at worst, it suffers setbacks; the Allies never achieve a breakthrough; at best they make inroads or deep inroads (ibid., 228).

Anti-Semitism is another manifestation of Nazi Manicheanism. While things Nazi cannot be praised too highly, Jews are demonized. Their names, their identity papers marked with a $J$ for Jude, the yellow stars of David that must be visible on their chests, single them out as a people to be shunned. They cannot practice their professions; they cannot go to the movies or to the library; they are subject to constant humiliation. Except for Jews, "Jewish" names are avoided; indeed, Jews without such easily identified names must interpose "Sara" or "Israel" to avoid any confusion (ibid., 77-78). While anti-Semitism can be displayed and codified, genocide must be concealed behind a veil of superimposed ignorance. As in the case of German defeats in battle, euphemism

\footnotetext{
${ }^{1}$ No translation can reflect the use of the word "du," an expression used in intimate circles, primarily among friends and family.
} 
comes to the rescue. Jews are not sent to their death; they have "gone away" (ibid., 169).

As a step toward their elimination, Jews are turned from people into "pieces" [Stück]. This subordination of the animate to the inanimate is what we might expect, simply as a product of antiSemitism. But a mechanical metaphor extends to the whole of the German people, who are, after all, only cogs in the machinery of Nazi triumph. Under the Nazis, everything is "organisiert," a favorite word: "again and again working people are compared to machines" (ibid., 155-56).

Nazi language is the deliberate product of Nazi propaganda. It is Joseph Goebbels and Alfred Rosenberg who make "what was previously the preserve of an individual or tiny group" into "common property" (ibid., 16). They do so, not by inventing and promulgating a new vocabulary, but by using the resources of the old, changing "the value of words and the frequency of their occurrence" (ibid., 16). It is thus that, by a conscious effort, unparalleled in history, the propaganda minister and the party philosopher create the linguistic network that generates the systematically distorted communication in which the fleeing Klemperer and his Lithuanian pharmacist find themselves caught. For those so caught, Nazi language is the norm: the ordinary way of expressing oneself in everyday situations, a reliable resource for describing the world and coping with its problems.

Like the Lithuanian pharmacist, most German people were self-deceived. They did not think they were mouthing Nazi ideology; they thought they were speaking the simple truth. Although they certainly recognized that they were using language with oppressive intent, they felt their victims richly deserved their fate. Systematically distorted communication that is so pervasive, so broad in its scope, seemingly leaves no refuge from which a critique may be mounted. Under the Nazis, a system designed to generate systematically distorted communication was deliberately put in place, ideologically generated, and hegemonically enforced. It was as broad in scope as the Nazi state itself and was supported by the full power of that state.

\section{Systematically distorted communication: sexist language}

Like Nazi language, sexist language is broad in scope, a feature of whole societies: two generations of sociolinguists have uncovered widespread patterns whose only common thread is the gendering of language, patterns that embody an ideology in which men are the primary source of economic, social, and political power, in which a stereotyped masculinity is the standard against which all human beings are measured. When a young airline passenger asks his 
wife-_How about some more coffee, hon?"- nothing but a request may be intended and nothing but intimacy need be presupposed. But when he addresses the same question to a middle-aged flight attendant, although he may understand it as an appropriate request, she will quite properly understand it as derogatory. In the context of a pubic language, the question is sexist; it reinforces differences in economic, social, and political power.

Patterns of sexist language, which exist across languages, are of three kinds: grammatical, lexical, and pragmatic. In languages generally, the masculine gender is the norm. In French and Italian, for example, when a man and a woman form the subject of a sentence, the male name always precedes the female; in French, gender concord requires a masculine plural ending: Pierre et Jeanne sont allés. Moreover, in language generally, masculine nouns are invariably the basis of their female counterpart: waiter, waitress (Pauwels 1998, 34-80).

Grammatical patterns are complemented by lexical ones. Societal naming practices commonly reserve certain names as masculine, others as feminine. If we claim that these practices are not inherently sexist, we will continue to be puzzled by our discomfort at such androgynous names as "Evelyn" (Smith 1985, 47; 50-53). Moreover, female names are common that are "diminutives" of their masculine counterparts: Paulette, Georgia (Pauwels 1998, 3480 ). In addition, words for sexual activity almost invariably have a masculine orientation. In French, for instance, of the 1300 synonyms for coitus only eighty define it from female point of view, one that is invariably passive (ibid., 55). Furthermore, collective nouns identified with the masculine gender tend to be neutrally descriptive or honorific, while their female counterparts are often pejorative: he is a professional, a secretary, a tramp; she is a professional, a secretary, a tramp. Finally, where there are differences in languages exclusive to men or women - and these differences are legion - the female expression is avoided by men. No man is likely to say: "Oh fudge, I can't do anything with my hair!" (Lakoff in Roman, Juhasz \& Miller 1994, 284).

Over three decades ago, Robin Lakoff had conjectured that sexist language was not only ideological; it was hegemonic as well: women were systematically denied access to power in communicative interactions (Roman, Juhasz \& Miller 1994). Further research has amply documented this conclusion. In general men take longer turns, interrupt more, and are more assertive in their use of language; for instance, they generally avoid tag questions that weaken assertions, tags such as "isn't it?" in “That's right, isn't it?" A British study of interaction concludes that

males were the principal architects of such encounters, regardless of which partner took the first turn. They pro- 
ceeded independently in their choice of topics, dictating the pace at which intimacy increased during the exercise, whereas females enabled a degree of consensus to emerge by matching the pace set ... The data are seen as consistent with traditional sex role stereotypes bearing on the control of personal relationships. (Ibid., 162.)

The linguistic dominance of men is an outward sign of their economic, social, and political dominance. Penelope Eckert and Sally McConnell-Ginet make this point tellingly:

Dominance is sustained by privileging in community practice a particular perspective on language, obscuring its status as one among many perspectives, and naturalizing it as neutral or "unmarked." The privileged can assume their own positions to be norms toward which everyone else orients; they can judge other positions while supposing their own to be invulnerable to less privileged assessment. This privileged relation to a symbolic system ... carries with it interpretive and evaluative authority that requires no explanation or justification. (Ibid., 452.)

What is the source of these widespread and pervasive linguistic patterns? It is difficult to believe that they were deliberately put in place or that they were, like Nazi language, consciously enacted to assert or reinforce male dominance; far more likely, they were an unintended consequence of a division of labor among huntergatherer tribes, a division founded on biological differences and supported by the social conditions imposed by hostile subsistence environments. There is little doubt, however, that these linguistic practices continued to be used - albeit largely unconsciously - to maintain male dominance in later social environments, situations in which relations between men and women did not depend so drastically on subsistence conditions. Finally, in even later social environments - ones even farther removed from subsistence conditions - sexist linguistic practices could be used quite consciously, and as such become an instrument of oppression; sexist language could be transformed into a tool for manipulation, a means of strategic action. For example, those who argue against, or dismiss feminist language reform are arguing for the continued and deliberate use of this instrument, despite their disclaimers.

The case of sexist language permits us to understand better the nature of systematically distorted communication. It demonstrates that, although self-deception can exist at the level of whole societies, it may nonetheless arise as a lingering and unintended consequence of prior social conditions. In this respect, sexist language contrasts with the conscious intent of Nazi language. In addition, 
while sexist language is pervasive, unlike Nazi language its pervasiveness is limited to just one aspect of social interaction. Finally, sexist language contrasts with Nazi language in that it is in no sense an instrument of state power. While institutions exist that support and generate sexist language, these were not designed for this purpose. It is for this reason that critique can lead to the elimination of sexist language, though not necessarily to the elimination of the sexism inherent in the institutions themselves.

\section{Systematically distorted communication: drug promotion}

The language of prescription drug promotion in the United Statesthe only country other than New Zealand that has direct to consumer advertising of prescriptions drugs - is limited in scope to a subsystem, in this case the subsystem of medical care. When a patient complained to Dr. John Abramson of epicondylar tendonitis, otherwise known as tennis elbow, the doctor suggested a range of ameliorative measures, including restringing his racket, using a forearm band, and using cold compresses to alleviate the pain. The man, he says,

listened patiently to all my suggestions. When I was done, he said, "My friends are getting good relief from Celebrex. Would you write me a prescription for that?" I explained that, despite what the ads implied, Celebrex would not provide him with any more relief than the other antiinflamatory drugs ... and was a lot more expensive. He replied that the additional cost was not a problem, "because my insurance covers it." [His] belief that Celebrex would solve his problem made him unwilling, or perhaps unable, even to consider my suggestions. And he made it very clear that if I would not prescribe Celebrex, he would find a doctor who would. (Abramson 2004, 7)

In this exchange, the patient uses the leverage provided by the medical insurance system to undermine his professional's judgment and, not incidentally, his own best interest. But only the patient is self-deceived. We need to look at the more interesting case in which the physician is self-deceived as well. We begin by scrutinizing the way the pharmaceutical industry interacts with the medical system.

Celebrex and Vioxx, its more notorious counterpart, are typical of a wide range of new drugs whose benefits over existing ones are at best slight and whose long-term deleterious side-effects are, in the nature of the case, unknown, as they have no substantial history of use. They are aimed largely at conditions that are, happily for 
the pharmaceutical industry, chronic, and at some conditions such as insomnia that are, at best, only marginally a concern of the medical community. Their creation is driven almost entirely by market considerations and their manufacturers have every incentive to exaggerate their efficacy, and the scope of their therapeutic effects, short of breaking the law.

Are the manufacturers of Celebrex and Vioxx, Pfizer and Merck, guilty of deception? In the case of Vioxx at least, lawsuits alleging deception have certainly multiplied. It seems true, from the numerous documents that Congressional hearings made public, that, rather than heed the warnings that Vioxx caused more heart attacks (though not more deaths) than its competitors, Merck increased the intensity of its marketing efforts. But blaming Merck for causing heart attacks is like blaming drunk drivers for causing traffic accidents, ignoring the fact that such drivers are components of a system that prefers the private automobile to public transportation, that made cars safer only under extreme pressure, that places drinking establishments next to highways, and that encourages drinking through extensive advertising (Gusfield 1981). This is not to say that no one is to blame; it is to say, rather, that there is plenty of blame to go around, that focusing on one guilty party-a chosen scapegoat-lets the others go scot-free; worse, it lets the system continue virtually uninterrupted. Drugs like Celebrex and Vioxx have become components of a system in which patients are cast as consumers, medical researchers as pharmaceutical company employees, and clinicians as bureaucratic functionaries.

It is this system that generates the problem exemplified in the tennis-elbow anecdote. In the case of Celebrex and Vioxx, we might say the drug company is to blame, but no patient needs to request these once over-prescribed, over-advertised drugs. We might say the physician is to blame for giving into the patient's wishes. But as a result of managed care, doctors spend very little time with patients, certainly not enough to argue them out of their preferences. At the same time, managed care has eroded the trusting relationship between physician and patient. Patients heed the television advertisements they see every evening, not the physician who sees them for ten minutes a year, and does not remember their names. Still, it is the physicians who are the gatekeepers; it is therefore they who are the focus of attention, not only of patients, but, more importantly, of the pharmaceutical industry. ${ }^{2}$

Drug companies spend a great deal of time and money persuading physicians to prescribe the medications they manufacture, trying to substitute their judgment for medical judgment. Not sur-

\footnotetext{
2 The situation has become more complicated as the insurance industry has tried to curb costs by controlling prescription practices, overriding both the patients' wishes and the physicians' best judgment.
} 
prisingly, there is a positive correlation between physicians' contact with the pharmaceutical industry and their prescribing practices: "doctors who report relying more on promotion prescribe less appropriately, prescribe more often, or adopt new drugs more quickly" ("Drug Information Data Base" 5). In one study, "doctors who interacted with a company were between 9 and 21 times more likely than other doctors to have requested that a drug made by that company be added to the [hospital] formulary" (ibid., 10). In addition, industry-supported studies in medical journals are more likely to report positive findings, regardless of the evidence, and to support additional expenditures and new and off-label treatments over standard ones (ibid., 15-16). Despite the heavy involvement of industry in funding research, a survey established that only $26 \%$ of North American medical journals required disclosure of any conflict of interest that might arise from drug company subsidies (ibid., 16). Finally, there is also substantial evidence that direct-toconsumer advertising influences both consumer and physician behavior:

In Prevention magazine's survey of consumers, 32\% of consumers who had seen a DTC [direct-to-consumer] advertisement had talked to their doctor about an advertised medicine. Twenty-six percent of these had asked for the advertised medicine. Of these $71 \%$ received a prescription for it, and 10\% received a prescription for another medicine. In Bell et al.'s study of Sacramento adults $19 \%$ reported having asked for a prescription, and 35\% having asked a doctor for more information, as a result of a DTC advertisement. (Ibid., 11.)

Another study reported that, where a patient requested an advertised drug, $50 \%$ of the doctors were ambivalent about treatment, compared to $12 \%$ where no request had been made (ibid., 11). These studies concern only manipulation and strategic action. Nevertheless, they speak volumes for the conditions that make physician self-deception possible.

To be deceived, physicians must be both convinced and convinced that they are not convinced. In a study of residents, for example, $84 \%$ felt that other physicians were affected by pharmaceutical industry gifts, but $82 \%$ felt that they were not (Steinman, Shlipak \& McFee 2003, 554). In another study, after returning from allexpense-paid sun-belt symposia, physicians prescribed more of the sponsoring drug company's drugs than before. However, the majority of those prescribing physicians were unaware of this change, and denied that enticements changed their prescribing practices (Orlowski \& Wateska 1992). Dana and Loewenstein point to the cause of this self-deception: 
These studies help to explain specifically how selfinterest affects decision making. First, individuals are unable to remain objective, even when they are motivated to be impartial, demonstrating that self-serving bias is unintentional. Second, individuals deny and succumb to bias even when explicitly instructed about it, which suggests that self-serving bias is unconscious. Third, the studies show that self-interest affects choices indirectly, changing the way individuals seek out and weigh the information on which they later base their choices when they have a stake in the outcome. (Ibid., 253.)

Despite their vast differences, in at least two respects, Nazi language and prescription drug promotion are alike. First, each attempts to control the behavior of significant others, not simply by persuading them, but also by persuading them that they have not been persuaded. Second, both cases are alike in that their seductive effect is not limited to a mass audience. The seduction of the American medical community parallels the Nazi seduction of the German academic, intellectual, and creative communities, a result that shows that talent and intelligence are insufficient guards against self-deception coincident with self-interest: even the physicianpatient relationship - a relationship of trust bound by an oath - can be infiltrated and undermined by the mobilization of self-interest to the detriment of patient health (Abramson 2004, 241-60). ${ }^{3}$

There are, of course, also significant differences between Nazi language and prescription drug promotion. While the Nazis intended to cause harm, the harm the pharmaceutical companies cause is incidental to the pressures of a highly competitive market. Although the positive effects of drugs on the improvement of human health can be easily be exaggerated-improved public measures, such as better sanitation, and changes in diet and exercise regimes, are probably more important - there is little doubt that drugs are strongly contributory. Moreover, while in the Nazi case, systematically distorted communication is the full-fledged expression of a hegemonic regime, in the drug case, by means of lobbying, a democratic regime is harnessed through legislation to particular commercial ends. Furthermore, the goal of this legislation is not, as in the Nazi case, ideological reinforcement, but ideological change: a transformation in which prescription medications become, not an integral aspect of medical practice, but a discretionary consumer

\footnotetext{
${ }^{3}$ In this respect, Nazi language, drug promotion, and sexist language are analogous in their effects: in their employment of sexist language, social and intellectual elites differed not a whit from the rest of the population.
} 
purchase. Finally, unlike Nazi language, the scope of drug promotion is severely limited. By its very nature, the pharmaceutical industry operates within a larger political and legal system. Consequently, the deleterious effects of the systematically distorted communication are constrained by federal regulatory agencies, especially the Food and Drug Administration, Congressional oversight, and the tort system. But these constraints are relatively feeble: FDA control is partial, Congressional oversight, fitful, and the tort system, cumbersome. Moreover, physician self-deception abetted by self-interest has proved a stubborn variable.

In sum, systematically distorted communication may pervade whole societies, or only one aspect or one segment of these societies. It may arise unintentionally, as a by-product of social interactions, or it may arise deliberately, driven by ideology. In the latter case, persuasion is a complex process: people must be persuaded to engage in systematically distorted communication and they must be persuaded, simultaneously, that they have not been persuaded. In all cases, however, the effects of systematically distorted communication cannot be achieved solely by persuasive means; persuasion must be abetted by institutional arrangements that embody hegemonic regimes. ${ }^{4}$

\section{Critique and Emancipation}

What is critique? It is the move from communicative action to discourse, the probing scrutiny of others' deepest convictions, and the contingent retreat from one's own, in order to reflect that, at bottom, these may be illusions. What is emancipation? It is freedom from one or another of these illusions, a state of mind that nevertheless rigorously excludes the Enlightenment's last illusion: the illusion that we are free of all illusions. By definition the victims of systematically distorted communication cannot share with their critics one of the essential presuppositions of the discourse that is the arena of critique: transparency concerning their motivation. If critique is to disabuse these men and women of their illusions, it

\footnotetext{
${ }^{4}$ Systematically distorted communication must be differentiated from the network of terms that characterize trades and professions. Surgeons in training interested in brain anatomy, for example, must master a complex set of interrelated terms: their mastery is a condition for entrance in their profession. Setting this condition is certainly an exercise of power over those desiring entry. Furthermore, as with systematically distorted communication, apprentices may master these terms with no thought of the rationale behind their conduct. But no self-deception is involved: there is a rationale for learning these terms, and it is available even to novices, should they inquire. Furthermore, the terms are functional, involved only in the practice of the trade or profession.
} 
must proceed in the absence of this presupposition. But it cannot proceed at all if it is not founded on plausible concepts of rationality and truth; absent the operation of these, critique cannot serve as an instrument of emancipation.

A model for emancipatory rationality may be found in therapeutic dialogues, in which psychoanalysts join forces with the residual rationality their neurotic patients retain. Freud puts it this way: "we desire ... that the ego, emboldened by the certainty of our help, shall dare to take the offensive in order to reconquer what has been lost" (Freud 1949, 72-73). Nevertheless, resistance to therapeutic critique is so stubborn that change is a long and complex process:

One must allow the patient time to become conversant with this resistance with which he has now become acquainted, to work through it, to overcome it, by continuing, in defiance of it, the analytical work according to the fundamental rule of analysis ... This working-through of the resistance may in practice turn out to be an arduous task for the subject of analysis and a trial of patience for the analyst. Nevertheless it is part of the work which effects the greatest changes in the patient and which distinguishes analytic treatment from any kind of treatment by suggestion. (Freud, his emphasis; quoted by Fisher and Greenberg 1985, 348-49.)

In therapeutic dialogue, there is no sense that analysts are mobilizing a rationality different from, or superior to that of patients; rather, in the interest of emancipation, they join forces with what rationality their patients retain.

Therapeutic critique need be grounded in nothing more than this minimalist concept of rationality; analysts and their patients need do nothing more than heed such logical fundamentals as the law of contradiction. ${ }^{5}$ This law may be taken as logically typical. Although it cannot be proved-Aristotle makes it clear that only the philosophically naïve would demand a proof-nevertheless it can be shown that its refutation is self-refuting, that I cannot assert that the book is and is not on this table at this instant. To signal clearly that the sphere of his theory consists of utterances rather than propositions, Habermas's version of this principle is rechristened the "performative contradiction": "A performative con-

\footnotetext{
${ }^{5}$ Cohen and Nagel make it clear that there are laws of thought other than the canonical three: contradiction, excluded middle, and identity (1934, 181-87).
} 
tradiction occurs when a constative speech act [an assertion] $k(p)^{6}$ rests on noncontingent presuppositions whose propositional content contradicts the asserted proposition $p$ " (Habermas 2001b, 80). The other traditional logical principles-excluded middle and identity-easily undergo this transformation.

Of course, critique, and the consensual insight to which it leads, is insufficient to secure patient emancipation. In part, this is because the consensus we achieve under this minimalist regime of rationality cannot be differentiated from erroneous views held in common. Habermas recognizes that such consensus is not truth; he affirms that "we associate 'truth' with a claim that transcends all potentially available evidence. This realist thorn prevents us from falling into a linguistic idealism that reduces 'truth' to 'warranted assertability" (Habermas 2003, 250; his emphasis). He also understands that "the gap between truth and justification cannot be closed even by [Peirce's solution] idealizing the conditions of the actual processes of justification" (ibid., 252).

Nevertheless, he feels that he has a solution to the problem: the world of experience "furnishes a justification-transcendent standard of orienting ourselves by context-independent truth claims - a standard that is always already presupposed in action" (ibid., 254). He claims that "the experience of 'coping' accounts for two crucial determinants of 'objectivity': the fact that the way the world is is not up to us; and the fact that it is the same for all of us. Beliefs are confirmed in action by something different than in discourse" (ibid., 254; his emphasis). While we can never escape from the self-deceptions that consensus occludes, we need never abandon a rationality that permits us to shed at least some of our illusions; while we can never assert that the truth is firmly in our possession, we can assert that our beliefs and our experience more nearly cohere. $^{7}$

It is the persistent struggle between malleable belief and obdurate experience under the sign of rationality that makes emancipation from systematically distorted communication possible. We do not merely agree that a Nazi bias against Jews parallels their bias against Lithuanians; our experience confirms its truth. We do not merely agree that sexist language is demeaning to women; we experience those practices as indeed demeaning. As physicians, we do not merely agree that prescription drug promotions exaggerate the benefits of certain new and expensive medications; we are rendered supremely uncomfortable by the incompatibility between our professional ethics and our prescribing practices.

\footnotetext{
${ }^{6} \mathrm{~K}$ is the illocutionary force of assertion, whereas $p$ is the proposition asserted.

${ }^{7}$ A more sophisticated version of this theory emerges as the scientific method.
} 
Still, minimalist concepts of truth and rationality cannot achieve emancipation tout court. Because the goal of such emancipation is permanent psychic and behavioral change, the resources of formal logic will always be insufficient. The full panoply of rhetorical proofs - those from ethos and pathos as well as those from logos - must be available to serve emacipation's cause. Emotion necessarily infiltrates the physician-patient exchange in our tenniselbow example and sexist practices have a strong emotional valence. In both cases, it is the passionate commitment to a distorting set of beliefs that must be overcome. In Klemperer's case, on the other hand, it is proofs from emotion and character that need to be deployed. Had Klemperer been able, by means of appropriate emotional appeals and appeals to character, to transform the Lithuanian pharmacist's friendship into compassion for his plight, he might also have been able to take a further, crucial step. He might have been able to convince her to "expand [her] powers of imagination" (Blum 1980, 510) and by so doing to feel compassion not merely for him, but for a whole class - all the Jews who were Hitler's victims. If so, Klemperer would have mobilized "the moral force of compassion" (ibid., 512), promoting the sense of equality it presupposes, the "sense of shared humanity, of regarding the other as a fellow human being" (ibid., 511).

Of course, the violence and structural violence of hegemonic regimes may easily trump the force of the better argument, however rhetorically enhanced. The underlying targets of critique are not opinions and attitudes but the social, political, and economic conditions that are the structural supports of systematically distorted communication. Even in liberal Western democracies, in which a degree of political freedom is institutionalized, it would be utopian to think that social change follows automatically from critique, no matter how cogent. The therapeutic experience leads us rather to expect that even in democracies the dissolution of regimes of systematically distorted communication will face resistances at least as stubborn as the most stubborn of neuroses. Unless power is actually redistributed, social, political, and economic change cannot occur. Unless such change occurs, systematically distorted communication will remain in force, as in the Nazi or the drug promotion cases, or it will disappear, as sexist language has, without necessarily undermining the hegemonic regimes that promote and reinforce sexist behavior.

In totalitarian regimes, no such distribution of power can take place absent countervailing power in the form of violence; in democratic regimes, in contrast, citizens have recourse to power short of violence: they can organize, they can lobby, they can protest, they can vote. In all regimes, however, totalitarian or not, it would be a mistake to underestimate the power of critique to uncover the uncomfortable truths whose perception is prerequisite to meaning- 
ful change: "the sociologist can and should delve into the repressed history of contemporary societies, bringing previously doxic assumptions, which serve the interests of élites, to the level of reflective argument" (Crossley \& Roberts 2004, 101). It is in such revelations that emancipation must begin.

\section{Conclusion}

Systematically distorted communication and its critique apply to scholarship as well. In a fine article Rhetorical Society Quarterly, "The Conduit Between Lifeworld and System: Habermas and the Rhetoric of Scientific Controversies," Nathan Crick and Joseph Gabriel (2010) apply two of Habermas's mature theoretical concepts to these controversies. The article does not question Habermas; it does not test his theory. Rather, the theory is regarded as an unquestioned explanatory resource. There is nothing wrong with this procedure; the mistake arises when scholars regard this as their only task. In so doing, they treat these texts as sacred; they confound endoxa and epistēm $\overline{\mathrm{e}}$. Victims of a form of systematically distorted communication, they refuse the reflexive moment; in terms of Habermas's mature theory of communicative action, they decline to shift to discourse. It is this shift that opens the door to a form of emancipation, a release from an intellectual bondage enforced by disciplinary hegemony. In this case, even etymology is illuminating: to emancipate in Roman law is to free a son from parental control. In his critique of Gadamer, Habermas makes the essential point:

Authority and knowledge do not converge. Certainly, knowledge is rooted in actual tradition; it remains bound to contingent conditions. But reflection does not wear itself out on the facticity of traditional norms without leaving a trace. It is condemned to operate after the fact; but, operating in retrospect, it unleashes retroactive power. ... The right of reflection requires that the hermeneutical approach limit itself. It requires a system of reference that transcends the context of tradition as such. Only then can tradition be criticized as well. $(1988,170)$

Self-deceived as to the truth of theories, scholars neglect testing them, refining them, and rejecting them when they prove inadequate in their encounters with the world. For scholars of argument, of rhetoric, of informal logic, what constitutes this world? It is constituted by cases on whose description and relevance to a particular problem we can all agree, and against which our theories must be measured. These should be chosen from a spectrum broad 
enough to permit plausible, if defeasible generalizations. To meet the challenge of a reflexive moment so defined is, I believe, to enact some version of George's comparative analysis. It is only by such means that we can measure our theoretical formulations against Habermas's minimalist concept of truth; it is only by such means that we can be certain that we can never be certain.

\section{References}

Abramson, John. (2004). Overdosed America: The Broken Promise of American Medicine. New York: Harper Collins Publisher.

Blum, Lawrence. (1980). "Compassion.” In Explaining Emotions. Amélie Oksenberg Rorty, pp. 507-17. Berkeley: University of California Press.

Blumer, Herbert. (1969). Symbolic Interactionism: Perspective and Methods. Englewood Cliffs, NJ: Prentice-Hall.

Calhoun, Craig (Ed). (1992). Habermas and the Public Sphere. Cambridge: MIT Press.

Cohen, Morris B. \& Ernests Nagel. (1934). An Introduction to Logic and the Scientific Method. New York: Harcourt, Brace, and Company.

Crick, Nathan \& Joseph Gabriel. (2010). "The Conduit Between Lifeworld and System: Habermas and the Rhetoric of Public Scientific Controversies." Rhetoric Society Quarterly, 40: 201223.

Crossley, Nick \& John Michael Roberts (Eds.). (2004). After Habermas: New Perspectives on the Public Sphere. Oxford: Blackwell.

Dana, Jason \& George Lowenstein. (2003). “A Social Science Perspective on Gifts to Physicians from Industry." JAMA, 290 (2): 252-55.

Dews, Peter (Ed.). (1986). Habermas: Autonomy and Solidarity: Interviews with Jürgen Habermas. London: Verso.

"Drug Information Data Base: What's Known and What is Missing." www.drugpromo.info/read-reviews.asp?id=4. Accessed $11 / 13 / 05$.

Eley, Geoff. (1992). "Nations, Publics, and Political Cultures: Placing Habermas in the Nineteenth Century." In Craig Calhoun (Ed.), Habermas and the Public Sphere, pp. 289-339. Cambridge: MIT Press.

Fisher, Seymour \& Roger P. Greenberg. (1985). The Scientific Credibility of Freud's Theories and Therapy. New York: Columbia University Press.

Freud, Sigmund. (1949). An Outline of Psychoanalysis. Tr. James Strachey. New York: W. W. Norton. 
George, Alexander L. (1982). "Case Studies and Theory Development." Presented to the Second Annual Symposium on Information Processing in Organizations, Carnegie-Mellon University, October 15-16. Pp. 53.

George, Alexander L. \& Timothy J. McKeown. (1985). "Case Studies and Theories of Organizational Decision Making." In Robert F. Coulam and Richard A. Smith (Eds.), Advances in Information Processing in Organizations: A Research Annual, pp. 21-58 Volume 2. Greenwich, CN: JAI Press.

Gusfield, Joseph. (1981). The Culture of Public Problems: Drinking-Driving and the Symbolic Order. Chicago: University of Chicago Press.

Habermas, Jürgen. (1970) “On Systematically Distorted Communication.” Inquiry, 13: 205-18.

Habermas, Jürgen. (1971). Knowledge and Human Interests. Trans. Jeremy J. Shapiro. Boston: Beacon Press.

Habermas, Jürgen. (1975). LTI: Notizbuch eines Philologen. Leipzig: Reclam Verlag.

Habermas, Jürgen. (1979). Communication and the Evolution of Society. Trans. Thomas McCarthy. Boston: Beacon Press.

Habermas, Jürgen. (1979) "What is Universal Pragmatics?" In Communication and the Evolution of Society. Trans. Thomas McCarthy. Boston: Beacon Press. Pp. 1-68.

Habermas, Jürgen. (1982). "A Reply to My Critics.” In John B. Thompson \& David Held. Habermas: The Critical Debates, pp. 219-83. Cambridge: The MIT Press.

Habermas, Jürgen. (1983). Philosophical-Political Profiles. Trans. Frederick G. Lawrence. Cambridge: The MIT Press.

Habermas, Jürgen. (1986). Habermas: Autonomy and Solidarity: Interviews with Jürgen Habermas. Peter Dews (Ed.). London: Verso.

Habermas, Jürgen. (1987a). The Theory of Communicative Action. Volume One. Reason and the Rationalization of Society. Trans. Thomas McCarthy. Boston: Beacon Press.

Habermas, Jürgen. (1987b). The Theory of Communicative Action. Volume Two. Lifeworld and System: A Critique of Functionalist Reason. Trans. Thomas McCarthy. Boston: Beacon Press.

Habermas, Jürgen. (1988). On the Logic of the Social Sciences. Tr. Shierry Weber Nicholsen \& Jerry A. Stark. Cambridge: MIT Press, (1967).

Habermas, Jürgen. (1992). Postmetaphysical Thinking: Philosophical Essays. Trans. William Mark Hohengarten. Cambridge: MIT Press.

Habermas, Jürgen. (1996). The Structural Transformation of the Public Sphere: An Inquiry into a Category of Bourgeois Society. Tr. Thomas Burger \& Frederick Lawrence. Cambridge: MIT Press. 
Habermas, Jürgen. (2001a). On the Pragmatics of Social Interaction: Preliminary Studies in the Theory of Communicative Action. Trans. Barbara Fuller. Cambridge: The MIT Press.

Habermas, Jürgen. (2001b). Moral Consciousness and Communicative Action. Trans. Christian Lenhardt \& Shierry Weber Nicholsen. Cambridge: MIT Press.

Habermas, Jürgen. (2002). The Language of the Third Reich. Trans. Martin Brady. London: Contniuum.

Habermas, Jürgen. (2003). Truth and Justification. Translated by Barbara Fultner. Cambridge: MIT Press.

Habermas, Jürgen. (2006). "Political Communication in Media Society: Does Democracy Still Enjoy an Epistemic Dimension? The Impact of Normative Theory on Empirical Research." Communication Theory, 16: 411-26.

Klemperer, Victor. (1975). LTI: Notizbuch eines Philologen. Leipzig: Reclam Verlag.

Klemperer, Victor. (2002). The Language of the Third Reich. Trans. Martin Brady. London: Continuum.

McCarthy, Thomas. (1982). The Critical Theory of Jürgen Habermas. Cambridge: MIT Press.

Mead, George Herbert. (1964). Selected Writings. Andrew J. Reck (Ed.). Chicago: University of Chicago Press.

Orlowski, J. P. \& L. Wateska. (1992) "The Effects of Pharmaceutical Firm Enticements on Physician Prescribing Patterns: There's No Such Thing as a Free Lunch." Chest, 102 (1): 27073.

Pauwels, Anne. (1998). Women Changing Language. London: Longman.

Roman, Camille, Suzanne Juhasz \& Christiane Miller (Eds.). (1994). The Women and Language Debate: A Sourcebook. New Brunswick: Rutgers University Press.

Smith, Philip M. (1985). Language, the Sexes, and Society. Oxford: Basil Blackwell.

Steinman, Michael A., Michael G. Shlipak \& Stephen J. McPhee. (2003). "Of Principles and Pens: Attitudes and Practices of Medical Household Staff toward Pharmaceutical Industry Promotions." American Journal of Medicine 110: 551-57.

Warren, Mark E. (1995). "The Self in Discursive Democracy." In Stephen K. White (Ed.), The Cambridge Companion to Habemas, pp. 167-200. Cambridge: Cambridge University Press.

Waxman, Henry. "Memoramdum: The Marketing of Vioxx to Physicians." May 5, 2005. 29 pages. www.ombwatch.org/article/archive/368. Accessed 11/13/05.

White, Stephen K. (1988). The Recent Work of Jürgen Habermas: Reason, Justice and Modernity. Cambridge: Cambridge University Press. 
360 Alan G. Gross

Williams, Raymond. (1977). Marxism and Literature. Oxford: Oxford University Press. 